\title{
Research on Theory and Experiment for Partially Covered PV/T Solar System
}

\author{
Lixian Xiao \\ Department of Physics and Electron Information \\ Science, Chuxiong Normal \\ Chuxiong, China \\ E-mail: xlx@cxtc.edu.cn
}

Yongtai $\mathrm{He}^{*}$

Department of Physics and Electron Information Science, Chuxiong Normal

Chuxiong, China

E-mail: hyt@cxtc.edu.cn

* Corresponding Author

\author{
Lei Li \\ Department of Physics and Electron Information \\ Science, Chuxiong Normal \\ Chuxiong, China \\ E-mail: lilei@cxtc.edu.cn \\ Ruiming Liu \\ Department of Physics and Electron Information \\ Science, Chuxiong Normal \\ Chuxiong, China \\ E-mail: liuruimingi@cxtc.edu.cn
}

\begin{abstract}
According to the structural features of partially covered photovoltaic/thermal (PV/T) solar system, the theory model and optimum design method of the partially covered PV/T solar system is established. The effect of different design parameters on the performance of the partially covered PV/T solar system is analyzed by using the theory model. Meanwhile, the prototype of the partially covered PV/T solar system was designed, and the characteristics of the partially covered PV/T solar system are studied by experiment at Chuxiong City. Experimental results show that the glass cover is essential for improving the thermal efficiency of the PV/T solar system, which related to the transmittance and thickness of the glass cover. In addition, the thermal efficiency will decrease with increasing covering area of the PV modules on the PV/T solar collector. Under the condition of the covering area of $0.8 \mathrm{~m} 2$ for the PV modules, the thermal efficiency and the output power of the prototype are $40.2 \%$ and $25.1 \mathrm{~W}$, respectively. Under the condition of covering area of $1.02 \mathrm{~m} 2$ for the PV modules, the thermal efficiency and output power of the prototype are $36 \%$ and $33.6 \mathrm{~W}$, respectively. Thus, the partially covered PV/T solar system has batter practicality, and can meet the need of the ordinary rural families in lighting electricity and hot water.
\end{abstract}

Keywords-Photovoltaic/thermal (PV/T); Partially Covered; Theory Mode; Practicability; Solar system

\section{INTRODUCTION}

The PV/T solar system was proposed by Kern and Russell[1]. The basic theory of the PV/T solar system was introduced, and the efficiency of solar energy could be more than $60 \%$ in theory[2]. In recent years, the PV/T solar system has been widely studied due to the aggravation of energy resources shortage[3]. For example, the integrated photovoltaic and thermal solar system (IPVTS) was studied by experiment[4]. The results showed that the primary energy saving efficiency of IPVTS exceeds 0.60 which was higher than for a conventional solar water heater or pure PV system. Rosell introduced the advantages of the PV/T solar system, and the low concentration technologies were combined into a $\mathrm{PV} / \mathrm{T}$ system to increase the solar energy conversion efficiency [5]. The thermal efficiency of the system reached $60 \%$. Coventry et al. developed the so called CHAPS (combined heat and power solar) PV/T collector, which the collector involves a parabolic trough of concentration ratio of 37 times with monocrystalline silicon cells and a twoaxis tracking system[6]. Bhargava et al. studied performance of PV/T system air heater in experiment and theory[7-10]. The theory thermal efficiency of PV/T systemcan reach 65\%[9].

In a word, PV/T solar system has higher solar energy conversion efficiency and business application value in theory. However, the practicability of PV/T solar system is worse due to the contradiction of working temperature of the PV/T collector and conversion efficiency[11-15]. In the paper, in order to improve practicability of PV/T system, the optimization design theory mode is established on the basis of the structure of partially covered PV/T solar collector and related theory, the effect of different design parameters on the output water temperature, and the output useful thermal energy and output power of the PV/T solar systems is analyzed. In addition, the prototype of the partially covered PV/T solar system is designed, and the characteristics are studied by experiment.

\section{THE DESIGN THEORY OF PV/T SOLAR COLLECT OR}

\section{A. Photothermal characteristics of PV modules}

In the photovoltaic generation, only $5-15 \%$ of incident solar radiation can be converted into electricity, with the greater percentage converted into heat. The temperature of the PV modules will rise with increasing of the incident solar radiation. The relationship between the temperature of the PV modules and the solar irradiation can be expressed[4] as follows: 


$$
t_{\text {cell }}=t_{a}+(N O C T-20) \cdot \frac{E_{a}}{800}
$$

Where, tcell is the temperature of the PV modules. ta is the ambient temperature. NOCT (Nominal Operating Cell Temperature) is defined as the PV module temperature in standard reference environment, defined as follows: solar irradiation $800 \mathrm{~W} / \mathrm{m} 2$, a mbient temperature $20^{\circ} \mathrm{C}$ and wind velocity $1 \mathrm{~m} / \mathrm{s}$. NOCT is $47^{\circ} \mathrm{C}$ for PV modules with plastic substrate. Ea is solar irradiation.

In addition, the photoelectric conversion efficiency of the PV modules will drop with the increase of the temperature for the PV modules. For the silicon PV modules, the conversion efficiency of the PV modules will drop $0.45 \%$ with the increase by $1 \mathrm{~K}$. The relationship between the photoelectric conversion efficiency and the temperature of the PV modules could be expressed [11] as follows:

$$
\eta_{e l}=\eta_{0}\left[1-0.0045\left(t_{\text {cell }}-298 K\right)\right]
$$

Among, $\eta 0$ is the photoelectric conversion efficiency of the temperature for the PV modules at $298 \mathrm{~K}$. tcell is the temperature of the PV modules.

There are two advantages to integrate the PV modules on the surface of flat plate thermal collector. Firstly, the heat of PV modules can be used to heating water or air, and the utilizing efficiency of solar energy is improved. Secondly, the temperature of PV modules will be dropped because the heat of PV modules is carried away by the water or air, the conversion efficiency of PV modules will be improved.

\section{B. Design and theory of PV/T solar collector}

The PV/T solar collector is designed by integrated the PV modules on the surface of flat plate thermal collector, which can simultaneous produce the electric energy and thermal energy. The inner structure of the PV/T solar collector is shown in Fig. 1. The total efficiency of the $\mathrm{PV} / \mathrm{T}$ solar collector involves the electric efficiency ( $\eta \mathrm{pv})$ and thermal efficiency ( $\eta$ th).

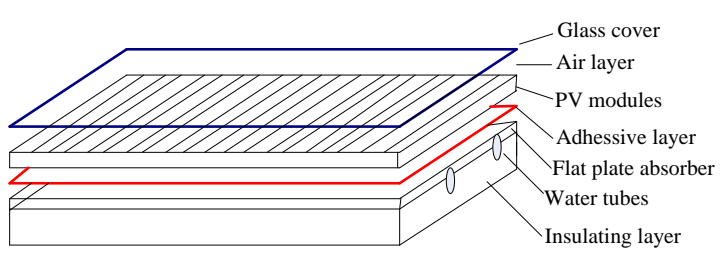

Figure 1. Inner structure diagram of PV/T solar collector

- Thermal efficiency model of PV/T solar collector

According to the structure of the PV/T solar collector, the useful heat $Q_{U}$ is given based on the theory of the flat plate thermal collector[16] as follows:

$Q_{U}=(1-\xi) A F_{t}\left[E_{a}(\tau a)_{e}-U_{L}\left(t_{m}-t_{a}\right)\right]+$ $\xi A F_{p v t}\left[\left(E_{a}(\tau a)_{e}-U_{L}\left(t_{m}-t_{a}\right)\right]\right.$

Where, $(\tau \alpha)$ e is the transmittance-absorptance product. $\mathrm{UL}$ is the overall collector heat loss coefficient. $\mathrm{tm}$ is the average temperature of thermal collector. ta is the temperature of the ambient. $\xi$ is the PV modules covering factor. $\mathrm{Ea}$ is the solar irradiation. Ft is the efficiency factor of the flat plate collector [16]. Fpvt is the efficiency factor of the PV/T solar collector. A is the overall area of PV/T solar collector.

Where, the efficiency factor of the PV/T solar collector can be expressed according to the structure of PV/T solar collector as follows:

$$
F_{p v t}=\frac{\frac{1}{U_{L}}}{W\left[\frac{1}{U_{L}\left[D+(W-D) F_{P}\right]}+\frac{1}{\mathrm{~W} \cdot h_{c a}}+\frac{1}{C_{b}}+\frac{1}{\pi D_{i} h_{f, i}}\right]}
$$

Where

$$
\begin{aligned}
& F_{P}=\frac{\tanh \left\lfloor m_{p}(W-D) / 2\right\rfloor}{m_{p}(W-D) / 2} \\
& m_{p}=\sqrt{\frac{U_{L}}{K_{a b s} \cdot L_{a b s}+K_{p v} \cdot L_{p v}}}
\end{aligned}
$$

Among, $\mathrm{W}$ is the tube spacing. $\mathrm{D}$ is the outside tube diameter. Di is the inside tube diameter. hca is the heat transfer coefficient of the bond between the flat plate collector and PV modules. hf.i is the heat transfer coefficient of fluid. $\mathrm{Cb}$ is the conductance of the bond between the fin and tube. Kabs is the thermal conductivity of the fin. Labs is the thickness of fin. Kpv is the thermal conductivity of the PV modules. Lpv is the thickness of the PV modules.

Thus, the thermal efficiency of PV/T collector can be expressed as follows:

$$
\begin{aligned}
& \eta_{t h}=\frac{Q_{u}}{A E_{a}}=(1-\xi) F_{t}(\tau a)_{e}+\xi F_{p v t}(\tau a)_{e}- \\
& {\left[\frac{(1-\xi) F_{t} U_{L}\left(t_{m}-t_{a}\right)}{E_{a}}+\frac{\xi F_{p v t} U_{L}\left(t_{m}-t_{a}\right)}{E_{a}}\right]}
\end{aligned}
$$

The hot water temperature can be expressed on the basis of the thermodynamics as follows:

$$
\begin{aligned}
& T_{f}=\frac{\left[(1-\xi) A F_{t}\left[E_{a}(\tau a)_{e}-U_{L}(N O C T-20) \cdot \frac{E_{a}}{800}\right]\right.}{m C_{p}}+ \\
& \frac{\xi A F_{p v t}\left[\left(E_{a}(\tau a)_{e}-U_{L}(N O C T-20) \cdot \frac{E_{a}}{800}\right]\right] t}{m C_{p}}+T_{i}
\end{aligned}
$$

Where, $m$ is the water mass. $C_{p}$ is the specific heat capacity of water. $T_{i}$ is the initial temperature of water.

- Electric efficiency of PV modules in PV/T solar collector

The output electric efficiency of PV modules can be expressed as follows:

$$
\eta_{p v}=\tau k \eta\left[1-0.0045\left(t_{a}+\left((N O C T-20) \cdot \frac{E_{a}}{800}-298 K\right)\right]\right.
$$

Where, $\tau$ is the transmittance of glass cover. $k$ is the output efficiency coefficient of PV modules, which shows the effect of working point on conversion efficiency of PV modules. $\eta$ is the conversion efficiency of PV modules. $t_{a}$ is the temperature of ambient.

The output power of PV modules can be expressed as follows:

$$
\begin{aligned}
& P_{o}=\tau k \eta \\
& {\left[1-0.0045\left(t_{a}+\left((N O C T-20) \cdot \frac{E_{a}}{800}-298 K\right)\right] A_{p v} E_{a}\right.}
\end{aligned}
$$

Where, $A_{p v}$ is the effective area of PV modules. 


\section{Characteristic analysis of the PV/T solar system}

The effect of the solar irradiation and covering area of $\mathrm{PV}$ modules on PV/T solar system is analyzed using the theory model of PV/T solar collector and the structure parameters of the PV/T solar collector (as Table 1).

T ABLE I. STRUCTURE PARAMETERS TABLE OFPV/T SOLAR COLLECTOR

\begin{tabular}{|c|c|}
\hline Parameter name & Value \\
\hline $\mathrm{PV} / \mathrm{T}$ solar collector area & $4 m^{2}$ \\
\hline Initial temperature of water $\left(T_{i}\right)$ & $293 / K$ \\
\hline $\begin{array}{l}\text { Emission coefficient of glass } \\
\text { cover }\left(\varepsilon_{g}\right)\end{array}$ & 0.88 \\
\hline $\begin{array}{l}\text { thermal conductivity of } \\
\text { insulating layer }\left(K_{e}\right)\end{array}$ & $\begin{array}{l}0.045 / \mathrm{W} . \mathrm{m}^{-} \\
{ }^{1} \cdot \mathrm{K}^{-1}\end{array}$ \\
\hline Perimeter of thermal collector $(P)$ & $8 / \mathrm{m}$ \\
\hline Thickness of fin $\left(L_{a b s}\right)$ & $0.002 / \mathrm{m}$ \\
\hline $\begin{array}{c}\text { Thickness of back insulating } \\
\text { layer }\left(L_{b}\right)\end{array}$ & $0.05 / \mathrm{m}$ \\
\hline $\begin{array}{l}\text { Thermal conductivity of the fin } \\
\qquad\left(K_{a b s}\right)\end{array}$ & $390 / \mathrm{W} \cdot \mathrm{m}^{-1} \cdot \mathrm{K}^{-1}$ \\
\hline Tube spacing $(W)$ & $0.095 / \mathrm{m}$ \\
\hline $\begin{array}{l}\text { Heat transfer coefficient of fluid } \\
\qquad\left(h_{f i}\right)\end{array}$ & $300 / \mathrm{W} \cdot \mathrm{m}^{-2} \cdot \mathrm{K}^{-}$ \\
\hline Transmittance of glass cover $(\tau)$ & 0.9 \\
\hline $\begin{array}{l}\text { Conversion efficiency of PV } \\
\text { modules }(\eta)\end{array}$ & $15 \%$ \\
\hline Glass cover lay er $(N)$ & 1 \\
\hline Water mass & $200 \mathrm{~kg}$ \\
\hline $\begin{array}{c}\text { Emission coefficient of collector } \\
\left(\varepsilon_{p}\right)\end{array}$ & 0.95 \\
\hline $\begin{array}{c}\text { Thickness of PV/T thermal } \\
\text { collector }\left(L_{p v}\right)\end{array}$ & $0.10 / \mathrm{m}$ \\
\hline $\begin{array}{l}\text { Thickness of side insulating layer } \\
\left(L_{e d g e}\right)\end{array}$ & $0.04 / \mathrm{m}$ \\
\hline Outside tube diameter $(D)$ & $0.02 / \mathrm{m}$ \\
\hline Inside tube diameter $(D i)$ & $0.015 / \mathrm{m}$ \\
\hline $\begin{array}{l}\text { Thermal conductivity of back } \\
\text { insulating layer }\left(K_{b}\right)\end{array}$ & $\begin{array}{l}0.045 / \mathrm{W} . \mathrm{m}^{-} \\
{ }^{1} . \mathrm{K}^{-1}\end{array}$ \\
\hline $\begin{array}{l}\text { Thermal conductivity of the PV } \\
\text { modules }\left(K_{p v}\right)\end{array}$ & $84 / \mathrm{W} \cdot \mathrm{m}^{-1} \cdot \mathrm{K}^{-1}$ \\
\hline $\begin{array}{l}\text { Heat transfer coefficient of the } \\
\text { bond between the Flat plate } \\
\text { collector and PV modules }\left(h_{c a}\right)\end{array}$ & $45 / \mathrm{W} \cdot \mathrm{m}^{-2} \cdot \mathrm{K}^{-1}$ \\
\hline $\begin{array}{c}\text { Conductance of the bond } \\
\text { between the fin and tube }\left(C_{b}\right)\end{array}$ & $45 / \mathrm{W} \cdot \mathrm{m}^{-1} \cdot \mathrm{K}^{-1}$ \\
\hline $\begin{array}{l}\text { Transmittance-absorptance } \\
\text { product }(\tau \alpha)_{e}\end{array}$ & 0.8 \\
\hline $\begin{array}{l}\text { Output efficiency coefficient of } \\
\text { PV modules }(k)\end{array}$ & 0.8 \\
\hline Temperature of the ambient $\left(t_{a}\right)$ & $293 / K$ \\
\hline
\end{tabular}

- $\quad$ Effect of solar irradiation and covering area on the photothermal characteristics

Under the condition of different covering area of PV modules, the relationship of PV/T solar system thermal efficiency and solar irradiation are shown in the Fig. 2

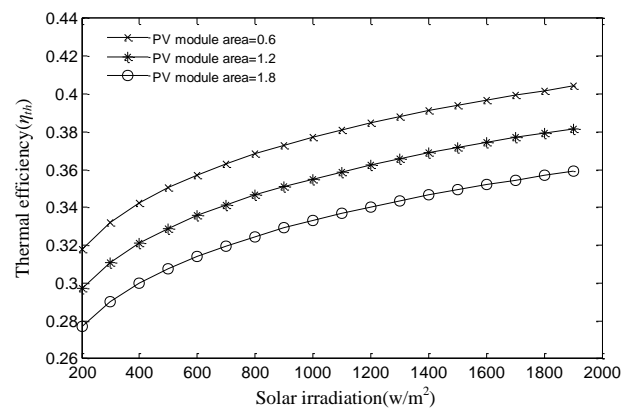

Figure 2. Effect of irradiance on system thermal efficiency

In Fig. 2, the thermal efficiency of PV/T solar system increase with increasing the solar irradiance, and the thermal efficiency of PV/T solar system decrease with increasing covering area of PV modules under same condition of the solar irradiance.

- Effect of solar irradiation and covering area on the output power characteristics

Under the condition of different covering area for PV modules, the relationship of PV/T solar system output power and solarirradiation are shown in the Fig. 3.

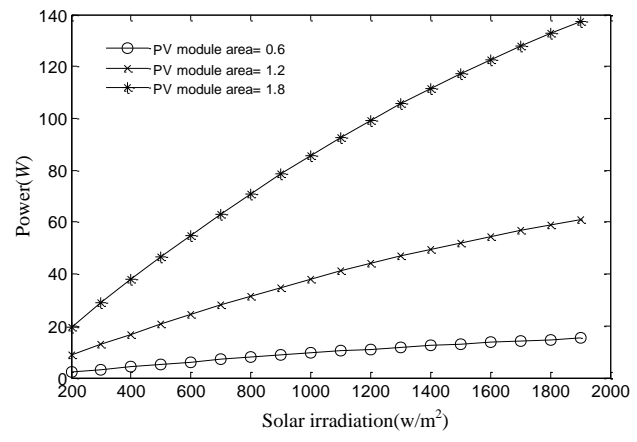

Figure 3. Effect of irradiance on system output power

In Fig. 4, the output power of PV/T solar system increase with increasing solar irradiance, and the output power increase with increasing covering area of PV modules under same condition of solar irradiance.

\section{PROTOTYPE OF THE PV/T SOLAR SYSTEM AND EXPERIMENT}

\section{A. Prototype of the partially covered PV/T solar system}

The prototype of partially covered PV/T solar system is designed, which consis ts of two partially covered flat plate $\mathrm{PV} / \mathrm{T}$ collectors with area of $2 \mathrm{~m}^{2}$, the water tank insulation of $200 \mathrm{~L}$, the silicic acid battery of $80 \mathrm{Ah}$ and the charge controller, etc. The covering area of PV modules is $0.8 \mathrm{~m}^{2}$ (the effective area of $0.68 \mathrm{~m}^{2}$ for the PV modules). The prototype is shown in the Fig. 4.

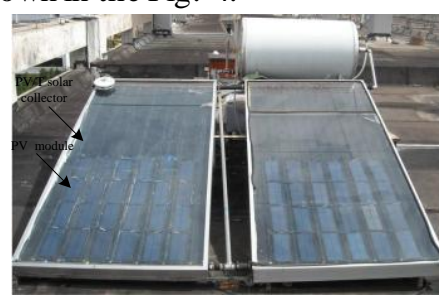

Figure 4. Prototype of the PV/T solar system 


\section{B. Experiment system and theory}

The experiment test system is designed which consisted of the multi-channel data acquisition system, the irradiance meter (TB-2), five temperature transmitters and platinum resistances, where TB-2 is used to measure the solar irradiance, The platinum resistance and the temperature transmitter are used to detect temperature signal and convert to voltage signal. All test results are stored in the computer through multi-channel data acquisition system. The test content include the solar irradiance, the environment temperature, the PV modules temperature, the water temperature, the PV modules output current and voltage, etc. The test system is showed in the Fig. 5.

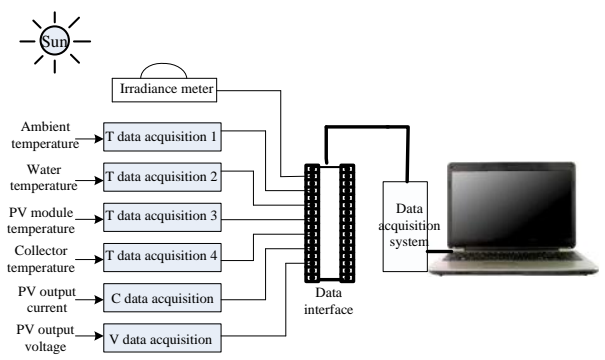

Figure 5. Test system structural diagram of the PV/T solar system

In addition, thermal efficiency $\eta_{t h}$ and output power of $\mathrm{PV} / \mathrm{T}$ solar system is defined using the thermodynamics theory and the electrician theory as follows:

$$
\begin{gathered}
\eta_{t h}=\frac{M C_{p}\left(T_{f}-T_{i}\right)}{H A} \\
P_{o}=U_{o} I_{o} \\
\eta_{p v}=\frac{P_{p v}}{A_{p v} E_{a}}
\end{gathered}
$$

Where, $M$ is the water mass in tank insulation. $C_{p}$ is the specific heat capacity of water. $T_{i}$ and $T_{f}$ are the initial temperature and highest temperature, respectively. $H$ is receiving overall energy per unit area in the whole measurement period. $P_{o}$ is the average output power of $\mathrm{PV} / \mathrm{T}$ system. $A$ is the overall area of $\mathrm{PV} / \mathrm{T}$ solar collector. $A_{p v}$ is the effective area of PV/T solar collector. $P_{p v}$ is the real time output power of $\mathrm{PV} / \mathrm{T}$ system.

\section{Prototype experiment and analysis}

Firstly, the effect of glass cover on the characteristics for the prototype of PV/T solar system is studied at Chu xiong City (from 8 April to 11 April, 2013). Under the condition of different glass covers (no glass cover, the thickness of $2 \mathrm{~mm}, 3 \mathrm{~mm}$ and $4 \mathrm{~mm}$ ) on PV/T solar collector, the hot water temperature, the solar irradiation, the PV modules temperatures, output voltage and current of PV modules are tested in the prototype. Experiment results show that the effect of the glass cover on the performance of the PV/T solar system is obvious. Under the condition without glass cover, the average output efficiency of PV modules is $6.4 \%$ at $8: 27-15: 27$, the heat efficiency is lower only $26.4 \%$, and the hot water temperature only reach $50^{\circ} \mathrm{C}$. Under the condition with glass cover, the thermal efficiency of electric efficiency the system related to the transmittance and thickness of glass cover. For example, under the glass thickness of $2 \mathrm{~mm}$, the thermal efficiency of system and the average output efficiency of the PV modules are $40.2 \%$ and $6.4 \%$, respectively. Under the glass thickness of $4 \mathrm{~mm}$, it's $28.0 \%$ and $5.3 \%$, respectively.

Secondly, the effect of the covering area of PV modules on the performance of PV/T solar system is studied by experiment at Chuxiong City (8 April, 2013 and 14 June, 2013). Covering areas of PV modules are $0.8 \mathrm{~m}^{2}$ and $1.01 \mathrm{~m}^{2}$, respectively (the effective areas of $0.68 \mathrm{~m}^{2}$ and $0.85 \mathrm{~m}^{2}$ for PV modules). The performances of two PV/T solar systems are tested at 8 April and 14 June, 2013. The solar irradiation, the temperature of PV modules and the PV output efficiency are showed in the Fig. 6.

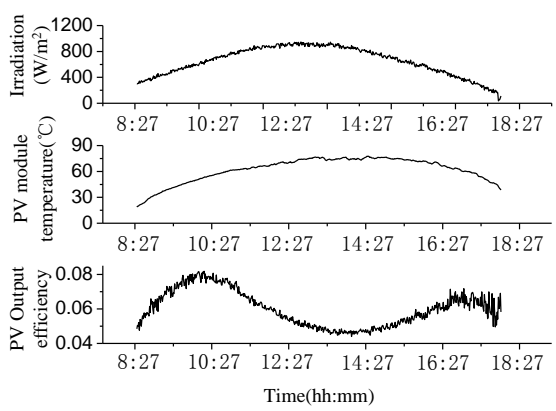

a. Prototype of covering area $0.8 \mathrm{~m} 2$

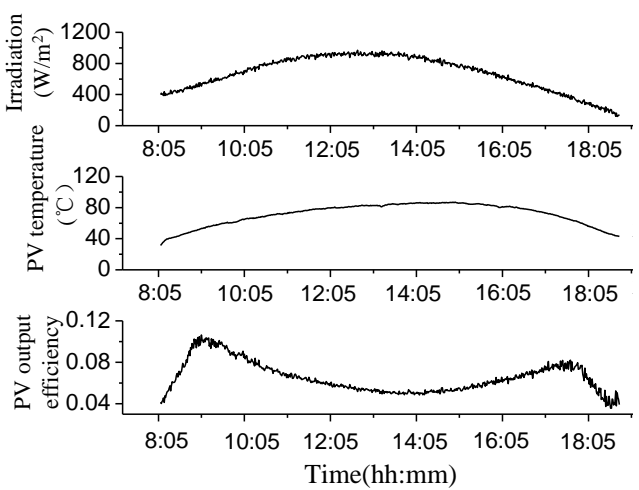

b. Prototype of covering area $1.01 \mathrm{~m} 2$

Figure 6. Characteristics of PV modules in the prototype

In the Fig. 6(a), the average solar irradiation is $725 \mathrm{~W} / \mathrm{m}^{2}$ at $8: 27-16: 27$. In the Fig. 6(b), the average solar irradiation is $770 \mathrm{~W} / \mathrm{m}^{2}$ at $8: 27-16: 27$. The temperature of $\mathrm{PV}$ modules rises with the increase solar irradiation. The output electric efficiency of the PV modules reduces with the increase of temperature. These results are consistent to the theory analysis.

Under the condition of two covering areas, the output power and water temperature of prototype are showed in the Fig. 7.

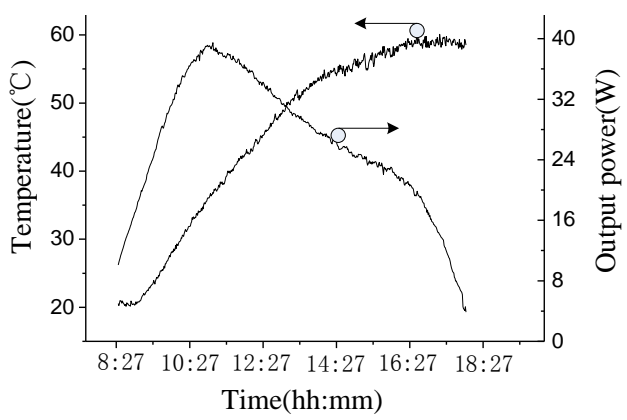

a.Prototype of covering area $0.8 \mathrm{~m} 2$ (8 April) 


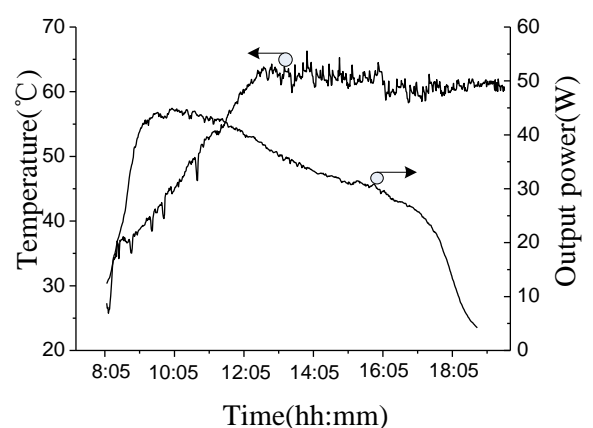

b. Prototype of covering area $1.01 \mathrm{~m}^{2}$

Figure 7. Characteristics of water temperature and power

In the Fig. 7(a), the hot water temperature reaches $60^{\circ} \mathrm{C}$, and the thermal efficiency is $40.2 \%$. In addition, the average output power of PV modules is $25.1 \mathrm{~W}$ from $8: 30$ 18:30. In the Fig. 7(b), the hot water temperature reaches $65^{\circ} \mathrm{C}$, and the thermal efficiency is $36 \%$. The average output power of PV modules is $33.7 \mathrm{~W}$ from 8:30-18:30. According to the experiment results, the thermal efficiency of prototype decreases with increasing covering area of PV modules. Experiment results are consistent to the theory analysis.

The experiment results show the output power of PV modules in the prototype can supply four energy-saving lamps (9W) to work for six hours at night. Hence, the prototype of PV/T solar system had batter practicality and could meet the basic need of the ordinary rural families in lighting electricity and hot water.

\section{CONCLUSION}

The optimization design theory of partially covered $\mathrm{PV} / \mathrm{T}$ solar system is established on the basis of the structure for PV/T solar collector, the basic theory of flat plate thermal collector and photothermal characteristics of PV modules. The effect of different design parameters on characteristics of the partially covered PV/T solar system is analyzed using the design theory. The design process of partially covered PV/T solar system can be simplified by using the design theory. The prototype of partially covered $\mathrm{PV} / \mathrm{T}$ solar system is designed, and the effect of glass cover and covering area of PV modules on the characteristics of the prototype is studied at Chuxiong City. Experiment results show that the glass cover is essential for improving the thermal efficiency of PV/T solar system, and the output electric efficiency and the thermal efficiency of the system related to the transmittance and thickness of glass cover. Moreover, the thermal efficiency of the PV/T solar system will decreases with increasing covering area of PV modules. Experiment results are consistent to the theory analysis. In addition, under the condition of covering area of PV modules $\left(1.02 \mathrm{~m}^{2}\right)$, the average output power of prototype is $33.7 \mathrm{~W}$ and the hot water temperature can reach above $65^{\circ} \mathrm{C}$. The electric energy of the prototype can supply four energy-saving lamps (9W) to work for six hours at night. So, the partially covered PV/T solar system has batter practicality, and can meet the basic need of the ordinary rural families in lighting electricity and hot water.

\section{ACKNOWLEDGMENTS}

The authors thank National Natural Science Foundation of China ( No.61271159) and Education department Major Project Foundation of Yunnan Province (No. zb2014014) for their financial supply.

\section{REFERENCES}

[1] [1] J. E. C. Kern and M. C.Russell, "Combined photovoltaic and thermal hybrid collector systems". 13th IEEE Photovoltaic Specialists, Washington, USA: 1978, 1153-1157.

[2] [2]L.W.Florschuetz, "Extension of the Hottel-Whillier model to the analysis of combined photovoltaic/thermal flat plate collectors", SolarEnergy, 1979,Vol22:361-366.

[3] [3] P. G. Charalambous, G. G.Maidment and S. A. Kalogirou, "Photovoltaic thermal (PV/T) collectors: A review", Applied Thermal Engineering, 2007, Vol 27:275-286.

[4] [4] B. J.Huang, T. H.Lin, W. C. Hung and F. S. Sun, "Performance evaluation of solar photovoltaic/thermal systems", Solar Energy, 2001, Vol 70:443-448.

[5] [5] J. I. Rosell, X.Vallverdu, M. A. Lechon and Ibanez, M. "Design and simulation of a low concentrating photovoltaic/thermal system", Energy Conversion and Management, 2005, Vol 46:30343046.

[6] [6] J. S.Coventry, "Performance of a concentrating photovoltaic/thermal solar collector", Solar Energy, 2005, Vol 78:211-222.

[7] [7] A. K.Bhargava, H. P. Garg and R. K.Agarwall, "Study of a hybrid solar system-solar air heater combined with solar cells", Energy Conversion and Management, 1991,Vol 31:471-479.

[8] [8] J. Zhao, N. Qin and ZH. Q.Duan, "The experimental research on solar cell and PV/T structure", Acta Energiae Solaris Sinica, 2009, Vol 30:327-331.

[9] [9] J. Sun and M. H. Shi, "Energy and exergy efficiency analysis of a solar concentrating PV/T air heating collector", Journal of Engineering Thermophysics, 2009, Vol 30: 1929-1932.

[10] [10]Ewa, Radziemska, "Performance Analysis of a PhotovoltaicThermal Integrated System", International Journal of Photoenergy, 2009, Vol 2009: ID 732093.

[11] [11] Swapnil, Dubey and S. C.Solanki, Arvind Tiwari, "Energy and exergy analysis of $\mathrm{PV} / \mathrm{T}$ air collectors connected in ser", Energy and Buildings, 2009,Vol 41: 863-870.

[12] [12] T. T. Chow and J. Ji, "Photovoltaic-Thermal Collector System for Domestic Application", Journal of Solar Energy Engineering, 2007,Vol 129:205-209.

[13] [13] P. G. Charalambous, S. A. Kalogirou, G. G.Maidment, "Optimization of the photovoltaic thermal (PV/T) collector absorber". Solar Energy, 2011,Vol 85:871-880.

[14] [14] V. V.Tyagi, S. C. Kaushik, and S. K.Tyagi, "Advancement in solar photovoltaic/thermal (PV/T) hybrid collector technology", Renewable and Sustainable Energy Reviews, 2012, Vol 16: 13831398.

[15] [15] Kamran, A. Moradi. M. Ebadian and X. L.Cheng,. "A review of PV/T technologies: Effects of control parameters". International Journal of Heat and Mass Transfer, 2013,Vol 64:483-500.

[16] Y. J. Luo, X. N. He and CH. G.Wang, Utilization technology of solar energy, Chemical Industry Press, 2006. 